\title{
The Relationships among Brand Equity, Brand Preference, and Purchase Intention: Empirical Evidence from the Motorbike Market in Vietnam
}

\author{
Tran Trung Vinh ${ }^{1} \&$ Le Van Huy ${ }^{1}$ \\ ${ }^{1}$ University of Economics, The University of Danang, Danang City, Vietnam \\ Correspondence: Tran Trung Vinh, University of Economics, The University of Danang, Danang City, Vietnam. \\ E-mail: trantrungvinh9@gmail.com
}

Received: December 15, 2015

Accepted: December 29, 2015 Online Published: February 25, 2016

doi:10.5539/ijef.v8n3p75

URL: http://dx.doi.org/10.5539/ijef.v8n3p75

\begin{abstract}
This study is aimed at exploring the effects of components of brand equity on overall brand equity; and the effects of overall brand equity on brand preference and purchase intention in the motorbike market in Vietnam. Based on a sample of 309 consumers, structural equation modeling (SEM) is used to test hypotheses. The research reveals that: (1) perceived quality, brand association and brand loyalty have positive effects on overall brand equity, but brand awareness has no effect on overall brand equity; (2) overall brand equity has positive impacts on brand preference and purchase intention; and (3) brand preference has a positive influence on purchase intention. These findings have implications for marketers.
\end{abstract}

Keywords: brand equity, brand preference, purchase intention, motorbike market

\section{Introduction}

Brand equity is a multidimensional and complex concept and this is one of the most concerned topics of research in recent years. Research of brand equity is not only studying about the brand equity but also focusing on both deeply measuring about the effects of marketing on building the brand equity (e.g. Yoo et al., 2000; Buil et al., 2013a) and impacts of brand equity on brand preference and purchase intention (e.g. Chang et al., 2008; Chen \& Chang, 2008; Tolba \& Hassan, 2009; Moradi \& Zarei, 2011). Although there are numerous research cases referring to the measurement of brand equity and its influence on consequences from other industries in various contexts, existing research on brand equity and its effect on brand preference and purchase intention in the Vietnamese motorbike market in particular is still sparse. Meanwhile, the motorbike market in Vietnam is the fourth biggest market in the world following China, India, and Indonesia; and is predicted to move to saturation point in 2020 when the average usage rate will reach up to three people per motorbike (Huy, 2013). However, this market seems to be at early steps to saturation point. The purchase power has recorded a dramatic decrease in recent years. The number of bought-motorbikes was 3.28 million, 3.27 million and 2.91 million in 2012,2013 and 2014 respectively (Hoang, 2015). This leads to higher and higher competition between brands and this is the period for strong brands to show their brand power. In this market, Honda has a big advantage regarding brand with a lot of favorite products that are kept in customers' subconscious for a long time like Cub, 67 and Dream. Even in the past, people used to refer to 'Honda' for motorbike in general. This fact proves the important role of brand and brand equity in the motorbike market. Therefore, the paper focuses on measuring the effects of band equity dimensions on overall band equity and the effect of overall band equity on brand preference and purchase intention in the motorbike market in Vietnam.

\section{Literature Review}

\subsection{Research Concepts}

\subsubsection{Brand Equity and Its Dimensions}

Brand equity is one of the main topics in marketing in recent years (Saydan, 2013). The literature on brand equity divides into studies from two different views: financial perspective and customer-based perspective (Keller, 1993; Chaudhuri, 1995; Chang et al., 2008). From the financial perspective, brand equity can be viewed as the financial asset value created for the business by brands (Lassar et al., 1995; Chang \& Liu, 2009). Simon 
and Sullivan (1993, p. 29) defined brand equity as "the incremental cash flows which accrue to branded products over and above the cash flows which would result from the sale of unbranded products". From the customer-based perspective (also known as customer-based brand equity), brand equity is founded on the evaluation of consumer response to a business by brand name (Chang \& Liu, 2009) and is considered as the value added to a product or service by a particular brand name (Chaudhuri, 1995). Aaker (1991, p. 15) defined brand equity as "a set of brand assets and liabilities linked to a brand, its name and symbol that add to or subtract from the value provided by a product or service to a firm and/or to firm's customers". According to Keller (1993, p. 2), brand equity can be defined as "the differential effect of brand knowledge on consumer response to the marketing of the brand". Comparing brand equity based on the financial perspective with customer-based perspective, brand equity based on customers is more supported by many scholars. If the brand does not have meaning to the customer, there are no other definitions, which are truly meaningful (Cobb-Walgren et al., 1995). Therefore, this study focuses on the customer-based perspective.

Regarding dimensions of brand equity, there are numerous components proposed in the analysis. Aaker (1991) separated it into five dimensions: perceived quality, brand loyalty, brand awareness, brand association, and other proprietary brand assets. The last component is usually ignored in marketing research because customers are not directly related to it (Saydan, 2013). Lassar et al. (1995) proposed to performance-giving, perceived value, image, trustworthiness and a feeling of commitment. Agarwal and Rao (1996) grouped it into two classes: overall quality and choice intention. Berry (2000) considered brand awareness and brand meaning as the main dimensions of brand equity.

Comparing these researchers, it is apparent that these dimensions of brand equity are quite similar to one that was proposed by Aaker (1991) such as brand association, brand awareness, brand loyalty, and perceived quality (Chang \& Liu, 2009). In addition, Aaker's model is the most cited and empirically tested in many previous research papers (Tong \& Hawley, 2009). Hence, dimensional model constructed by Aaker (1991) will be applied in this study.

Perceived quality is "the consumer's judgment about a product's overall excellence or superiority" (Zeithaml, 1988, p. 3). Perceived quality differs from objective or actual quality. Perceived quality is based on consumers' recognition while objective quality is based on the basis of product or manufacturing orientation (Garvin, 1983).

Brand awareness is defined as "the ability of the potential buyer to recognize and recall that a brand is a member of a certain product category" (Aaker, 1991, p. 61). Brand awareness involves brand recall and brand recognition. Brand recall implies when consumers see a product category, they can recall a brand name correctly, and brand recognition implies consumers have the ability to recognize a brand when they get some cues (Chi et al., 2009).

Brand association is "anything linked in memory to a brand" (Aaker, 1991, p. 109). Aaker (1991) believed that a brand association has a level of strength, and the link to a brand will be stronger when it is based on many experiences or exposures. Brand associations may reflect characteristics of the product (Jalilvand et al., 2011).

Brand loyalty is defined as "a deeply held commitment to rebuy or repatronize a preferred product or service consistently in the future, despite situational influences and marketing efforts having the potential to cause switching behavior" (Oliver, 1997, p. 392). Brand loyalty is a major component of brand equity.

\subsubsection{Brand Preference and Purchase Intention}

Keller (1993) emphasizes consumer responses (brand responses) as one of the main consumer-related dimensions of brand equity. This study mentions two aspects of consumer responses, which are brand preference and purchase intention. These are proposed by many previous researchers (e.g., Chen \& Chang, 2008; Chang \& Liu, 2009; Tolba \& Hassan, 2009; Moradi \& Zarei, 2011).

Brand preference is the bias a consumer shows when choosing a specific brand among alternatives based on the benefit or value it provides (Chang \& Liu, 2009). Brand preference is measured by the degree to which a person views a focal brand as preferable to a referent brand (Tolba \& Hassan, 2009).

Purchase intention is considered as a subjective inclination toward a product and can be an important index to predict consumer behavior (Fishbein \& Ajzen, 1975). It refers to the customers' ability to repurchase the brand in the future (Cronin et al., 2000; Tolba \& Hassan, 2009). As this study is concerned with motorbike brands, purchase intention is defined as the willingness to continue purchasing the motorbike provided by specific brands. 


\subsection{Relationships between Research Concepts}

\subsubsection{Effects of Brand Equity Dimensions on Overall Brand Equity}

Perceived quality is the "core" facet of brand equity. Perceived quality advances value to a brand in several ways. High-perceived quality leads and gives consumers a suitable reason to choose the brand, to allow the brand to charge a premium price, and to have a strong basis for the brand extension (Aaker, 1991; Saydan, 2013). Moreover, high-perceived quality means that over the experience related to the brand, consumers identify the differentiation and superiority of the brand (Yoo et al., 2000). Therefore, it is suggested that the higher the perceived quality, the higher brand equity (Yoo et al., 2000; Buil et al., 2013b). Hence, the following hypothesis of the relationship between perceived quality and brand equity is suggested:

H1a: Perceived quality has a significant positive direct effect on brand equity.

Brand awareness is an important element of brand equity. Brand awareness is the first step to creating brand equity (Buil et al., 2013b). Awareness is a prerequisite for brand and customer-based equity. Brand equity occurs when the consumer has a high level of awareness (Jalilvand et al., 2011). Brand awareness can be a sign of quality and commitment, making consumers familiar with a brand (Aaker, 1991); and it helps a purchaser consider the brand at the point of purchase, which leads to a favorable behavior for the brand (Yoo et al., 2000). Based on relationships above of brand awareness and brand equity in the literature, the following hypothesis is formulated:

H1b: Brand awareness has a significant positive direct effect on brand equity.

Rio et al. (2001) suggested that brand association is a vital factor in brand equity formation and management. It means that high brand equity implies that consumers have strong positive associations with respect to the brand. Aaker (1991) proposed that brand associations could provide value for the firm and its customers by differentiating the brand, by creating positive attitudes/feelings, giving a reason for consumers to purchase the brand and provide a basis for extensions. Customer-based brand equity is beginning to take shape when consumers have a high level of awareness and hold some strong, favorable, and unique brand associations in their memories (Tong \& Hawley, 2009). Hence, the following hypothesis of the relationship between brand association and brand equity is proposed:

H1c: Brand association has a significant positive direct effect on brand equity.

Brand loyalty is at the heart of brand equity. Brand loyalty makes consumers purchase a brand habitually and prevents switching to competitors' brand (Yoo et al., 2000). According to Aaker (1991), brand loyalty contributes important value to a brand because it provides a set of constant purchasers for a long period. Loyal consumers present more positive responses to a brand than non-loyal consumers do (Grover \& Srinivasan, 1992). Moreover, loyal customers are less likely to switch to another brand simply due to price, and they purchase routinely more than comparable non-loyal customers do (Bowen \& Shoemaker, 1998). Hence, brand loyalty will add to growing brand equity. Based on the relationship between brand loyalty and brand equity as mentioned, the following hypothesis is raised:

H1d: Brand loyalty has a significant positive direct effect on brand equity.

\subsubsection{Effect of Brand Equity on Brand Preference}

Several authors have emphasized the significance of building brand equity, which carries the advantage to the firm of more consumer brand preference (Chang et al., 2008). The literature proposes that strong brands catch preferential assessment as well as higher overall preference (Hoeffler \& Keller, 2003). A lot of empirical evidence indicated that brand equity could affect brand preference in various contexts. Myers (2003) employed a longitudinal study to examine the influence of brand equity on brand preference in the high involvement soft drink category, the result revealed a strong relationship between brand equity and brand preference. Similarly, Buil et al. (2013b) used three sets of brands; involving sportswear, electronics, and car product categories to investigate the effect of brand equity on brand preference. The result also showed that brand equity strongly effected brand preference. Other researchers (e.g. Cobb-Walgren et al., 1995; Chang et al., 2008) pointed out that high equity is associated with high brand preference. This relationship is hypothesized as follows:

H2a: Brand equity has a significant positive direct effect on brand preference.

\subsubsection{Effect of Brand Equity on Purchase Intention}

Brand equity also has a positive effect on purchase intention. Researchers have found empirical evidence that demonstrates a positive relationship between brand equity and purchase intention. For example, Cobb-Walgren et al. (1995) explored the impact of brand equity on purchase intention by using two sets of brands, one from a 
service category (hotels) and one from a lower risk product category (household cleansers). Across categories, the results showed that the brand with the higher equity in each category created significantly greater purchase intentions. Similarly, other results from various studies (e.g. Chen \& Chang, 2008; Chang \& Liu, 2009; Moradi $\&$ Zarei, 2011) as well pointed out that brand equity could affect purchase intention. In summary, brand equity is generally believed to be a significant contributor to purchase intentions, hypothesized as follows:

$\mathrm{H} 2 \mathrm{~b}$ : Brand equity has a significant positive direct effect on purchase intention.

\subsubsection{Effect of Brand Preference on Purchase Intention}

According the theory of reasoned action that is used to explain the relationships between attitudes, intentions and behavior (Fishbein \& Ajzen, 1975), a favorable attitude towards a brand leads to purchase intention (Buil et al., 2013b). Moreover, Cobb-Walgren et al. (1995) mentioned that higher equity brands create greater purchase intention. As brand equity is reflected in brand preference, it could be inferred that brand preference would be reflected in purchase intention. Similarly, empirical evidences from researches (e.g. Chen \& Chang, 2008; Chang \& Liu, 2009; Tolba \& Hassan, 2009; Moradi \& Zarei, 2011) supported the positive relationships between preference and purchase intention. Therefore, this is hypothesized as follows:

H3: Brand preference has a significant positive direct effect on purchase intentions.

\subsection{Conceptual Framework and Research Hypotheses}

Based on relationships above, a conceptual framework and hypotheses are illustrated in Figure 1. This figure shows the relationships between brand equity components and overall brand equity; the relationships between overall brand equity, brand preference and purchase intention; and the relationship between brand preference and purchase intention.

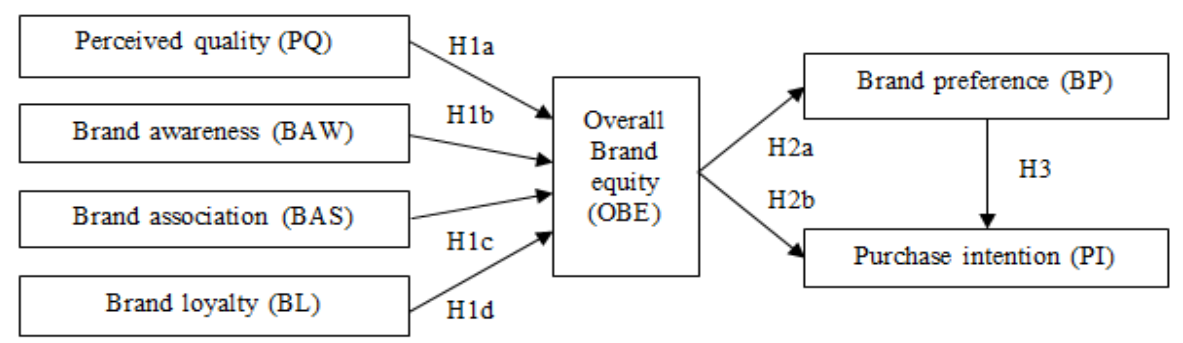

Figure 1. Conceptual framework

\section{Methodology}

\subsection{Sample and Procedure}

To examine the effects of brand equity components on overall brand equity and effects of overall brand equity on brand preference and purchase intention, we collected data using surveys at three cities of Hanoi, Danang, and Ho Chi Minh (HCM). The targeted respondents were those who own motorbikes. The data was gathered over three weeks, from 4th May 2015 to 1st July 2015. In total, 320 questionnaires were collected. However, eleven questionnaires were excluded from the analyses because they were incomplete, resulting in 309 valid questionnaires (Table 1). The questionnaire was managed in Vietnamese. The resulting questionnaire was originally drafted in English, translated into Vietnamese, and then back translated into English to make sure that the items were original.

Table 1. Demographic profile of the respondents

\begin{tabular}{|c|c|c|c|c|c|c|c|c|c|}
\hline \multirow{2}{*}{\multicolumn{2}{|c|}{ Brand }} & \multicolumn{3}{|c|}{ Area } & \multicolumn{2}{|c|}{ Gender } & \multicolumn{3}{|c|}{ Income ( $\$ 1.000 /$ year) } \\
\hline & & Hanoi City & Danang City & HCM City & Male & Female & $\leq 2$ & $2-5$ & $\geq 5$ \\
\hline Honda & 147 & \multirow{6}{*}{55} & \multirow{6}{*}{159} & \multirow{6}{*}{95} & \multirow{6}{*}{191} & \multirow{6}{*}{118} & \multirow{6}{*}{47} & \multirow{6}{*}{204} & \multirow{6}{*}{58} \\
\hline Yamaha & 71 & & & & & & & & \\
\hline Suzuki & 29 & & & & & & & & \\
\hline SYM & 27 & & & & & & & & \\
\hline Piaggio & 19 & & & & & & & & \\
\hline Other brands: & 16 & & & & & & & & \\
\hline
\end{tabular}




\subsection{Measurement Model}

Previous studies provided the basis for the choice of the measurement for the survey. The measurement uses a five-point Likert scale, ranging from "strongly disagree" (1) to "strongly agree" (5).

This paper used three-item scales adapted from Tong and Hawley (2009) measured perceived quality, brand awareness, and overall brand equity. Similarly, a measure for brand association was adopted from Tong and Hawley (2009), with four items. This research measured brand loyalty and was measured by using three items adapted from Yoo et al. (2000). This study measured brand preference by adopting the scale proposed by Chen and Chang (2008). Finally, borrowed from Cronin et al. (2000), three-items were used to capture purchase intention.

Data analysis follows three steps. Firstly, exploratory factor analysis (EFA) to determine the appropriate number of factors to be utilized in the analysis and Cronbach's alpha analysis to measure reliability coefficient for the items of each construct. Secondly, confirmatory factor analysis (CFA) for model to test the adequacy of the measurement models. Thirdly, structural equation modeling is used to analyze relationships between latent constructs and test research hypotheses.

\section{Research Analysis and Result}

\subsection{Exploratory Factor Analysis and Cronbach's Alpha Analysis}

The study uses principal component analysis with varimax rotation to extract main factors. The result showed that nine factors were extracted with a cumulative explained variance is $=67.740 \%(>50 \%)$ at the Eigen-value is 1.315 (Table 2). All the indicators were significant with factor loadings higher than 0.5 and will be remained for the next, except for observed variables BAS1 had factor loadings less than 0.5 and to be eliminated.

Table 2. Exploratory factor analysis

\begin{tabular}{|c|c|c|c|c|c|c|c|}
\hline & \multicolumn{7}{|c|}{ Components } \\
\hline & 1 & 2 & 3 & 4 & 5 & 6 & 7 \\
\hline PQ1 & & & .846 & & & & \\
\hline PQ2 & & & .880 & & & & \\
\hline PQ3 & & & .760 & & & & \\
\hline BAW1 & .837 & & & & & & \\
\hline BAW2 & .891 & & & & & & \\
\hline BAW3 & .873 & & & & & & \\
\hline BAS1 & & .457 & & & & & \\
\hline BAS2 & & .842 & & & & & \\
\hline BAS3 & & .823 & & & & & \\
\hline BAS4 & & .740 & & & & & \\
\hline BL1 & & & & & & & .767 \\
\hline BL2 & & & & & & & .814 \\
\hline BL3 & & & & & & & .826 \\
\hline OBE1 & & & & .783 & & & \\
\hline OBE2 & & & & .782 & & & \\
\hline OBE3 & & & & .782 & & & \\
\hline BP1 & & & & & .773 & & \\
\hline BP2 & & & & & .838 & & \\
\hline BP3 & & & & & .812 & & \\
\hline PI1 & & & & & & .822 & \\
\hline PI2 & & & & & & .831 & \\
\hline $\mathrm{PI} 3$ & & & & & & .749 & \\
\hline Eigen-value & 3.574 & 2.378 & 2.115 & 2.060 & 1.803 & 1.658 & 1.315 \\
\hline Extraction Sums of Squared Loadings & 16.244 & 10.810 & 9.615 & 9.363 & 8.197 & 7.535 & 5.976 \\
\hline
\end{tabular}

After above deletion, in order to assess the initial reliability of the measures, Cronbach's alpha and the item-total correlation for all scales were used. Cronbach's alpha for all the constructs (Table 3) were above 0.60 (Nunnally $\&$ Burnstein, 1994). Additionally, the item-to-total correlations were all above the threshold of 0.30 . Therefore, observed variables of each scale are retained in confirmatory factor analyses (CFA). 
Table 3. Cronbach's Alpha, composite reliability, and average variance extracted

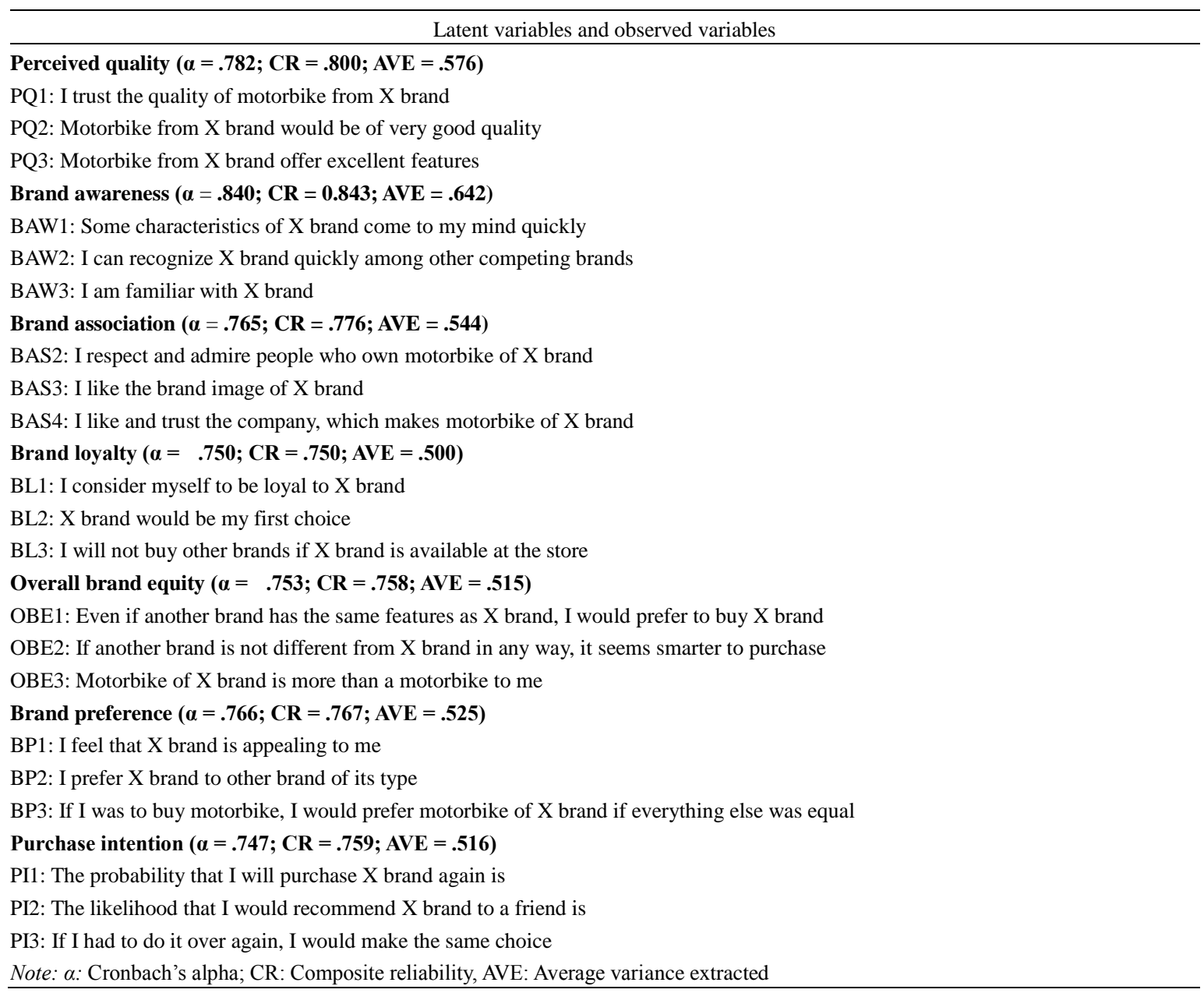

\subsection{Confirmatory Factor Analysis}

A confirmatory factor analysis (CFA) with Amos 21 Graphics software (SEM package) for the measurement model with nine constructs was performed. The goodness-of-fit statistics indicated that all criteria met the recommended values in the measurement model (model fit criteria suggested by Hu \& Bentler, 1999): $\chi 2 / \mathrm{df}=$ $1.554(<2), \mathrm{p}<0.01 ; \mathrm{GFI}=0.926 \& \mathrm{CFI}=0.954(>0.9) ; \mathrm{AGFI}=0.898(>0.8) ; \mathrm{RMR}=0.032 \&$ RMSEA $=$ $0.042(<0.1)$. Moreover, all factor loadings are above 0.5 and statistically significant. In addition, the average variance extracted (AVE) varied from 0.500 to 0.642 thus satisfying the criteria of 0.50 ; and the composite reliability (CR) varied from 0.750 to 0.843 are greater than 0.7 , thus satisfying the criteria of 0.70 (Table 3), which guarantee the internal validity of the measurement model (Bagozzi \& Yi, 1988). Furthermore, results support the discriminant validity of the scales. The discriminant validity of the scales evaluated for all any two constructs and all $\chi^{2}$ differences were significant.

\subsection{Structural Model}

According to proposed model, a structural equation modeling (SEM) was developed to assess the relationships between overall brand equity and its dimensions, the relationships among overall brand equity, brand preference and purchase intention (Figure 2). The fit statistics $\chi^{2} / \mathrm{df}=1.537(<2), \mathrm{p}<0.01 ; \mathrm{CFI}=0.951 \&$ GFI $=0.921(>$ $0.9)$; AGFI $=0.900(>0.8)$; RMSEA $=0.042 \&$ RMR $=0.040(<0.1)$ were all indicative of a good fit (model fit criteria suggested by Hu \& Bentler, 1999). 


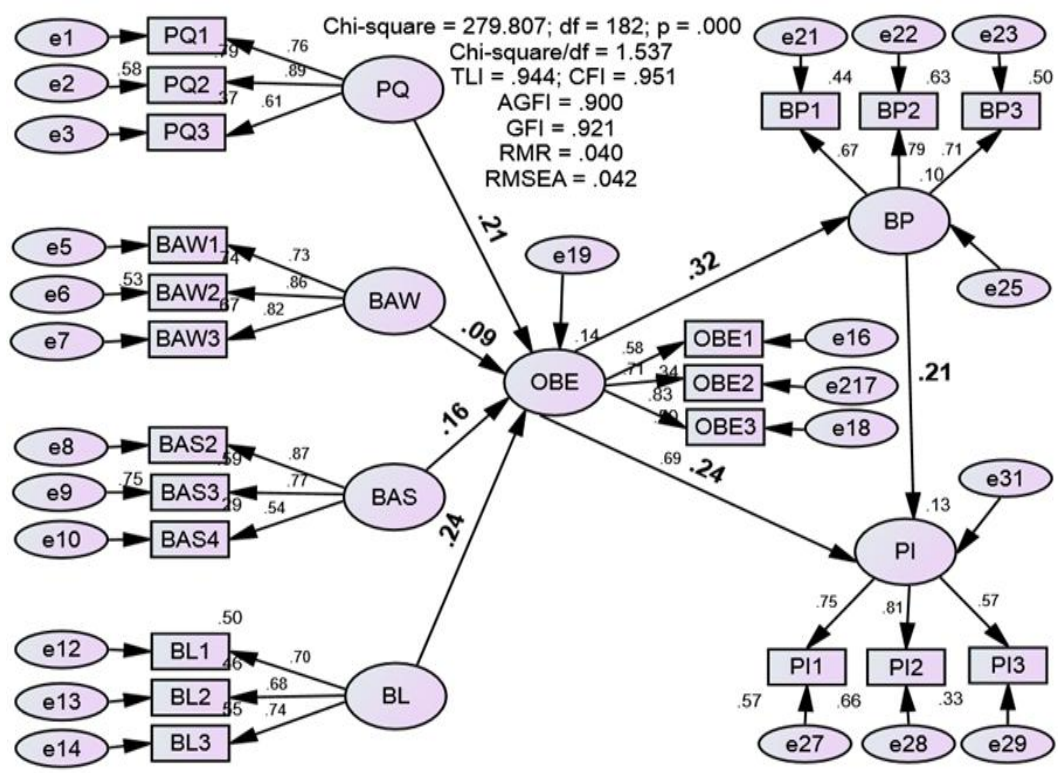

Figure 2. The SEM finalized model and results

Apart from the model's general fitted for the data, in order to determine the validity of the hypothesized, the statistical significance of all structural parameter estimates was examined as well. Firstly, with respect to the effects dimensions of brand equity had on overall brand equity, the results provided strong support for H1a, H1c and H1d, which indicated the positive and direct roles of perceived quality (SEs $=0.210, p=0.003$ ), brand association (SEs $=0.165, \mathrm{p}=0.018)$ and brand loyalty $(\mathrm{SEs}=0.245, \mathrm{p}=0.001)$ in affecting overall brand equity. However, the relationship of brand awareness to overall brand equity was weak and insignificant $(p=0.183)$. Therefore, hypothesis H1b is refused. Secondly, regarding the relationships between overall brand equity and consumer response aspects, results revealed a significant positive relationship between overall brand equity and brand preference and purchase intention, in support of H2a (SEs $=0.319 ; \mathrm{p}=0.000) ; \quad \mathrm{H} 2 \mathrm{~b}$ (SEs $=0.238 ; \mathrm{p}=$ 0.003 ). Finally, brand preference has significant positive influence on purchase intention ( $\operatorname{SEs}=0.210 ; p=0.008$ ) then $\mathrm{H} 3$ is supported (Table 4).

Table 4. Results of hypotheses testing

\begin{tabular}{cccccc}
\hline Relationships & Standardized estimate (SEs) & SE & CR & P-value & Results \\
\hline OBE <- PQ (H1a) & .210 & .049 & 3.006 & .003 & Supported \\
OBE <-BAW (H1b) & .089 & .041 & 1.330 & .183 & Unsupported \\
OBE <- BAS (H1c) & .165 & .042 & 2.372 & .018 & Supported \\
OBE <- BL (H1d) & .245 & .061 & 3.230 & .001 & Supported \\
BP <- OBE (H2a) & .319 & .096 & 4.042 & .000 & Supported \\
PI <- OBE (H2b) & .238 & .092 & 2.961 & .003 & Supported \\
PI <- BP (H3) & .210 & .075 & 2.653 & .008 & Supported \\
\hline
\end{tabular}

Note. SE: Standard error; CR: Critical ratios.

\section{Conclusion and Recommendations}

Brand equity is an essential concept for modern organizations and one of the hot topics of researching. Studying about brand equity is not only measuring brand equity but also doing research on how it influences on brand preference and purchase intention. In the Vietnamese motorbike market, the continuous and dramatic decrease in the level of purchases in recent years is clear evidence for the early coming of saturation. This fact makes high competition between brands more aggressive. Therefore, this is the period for brands in general and brand equity in particular to show their roles more than ever. That is the reason why our paper's purpose is to focus on measuring the effects of components on overall brand equity and how brand equity affects brand preference and 
purchase intention in the motorbike market. Based on theories and empirical researches, we propose a research model and then test hypothesis with 309 customers who own motorbikes. The results show that the proposed researching model generally fitted for the data. In terms of hypothesis, the results reveals that: (1) except for brand awareness, other components including perceived quality, brand association, and brand loyalty positively affect overall brand equity; (2) overall brand equity has positive influences on brand preference and purchase intention; and (3) brand preference directly and positively effects on purchase intention. These outcomes are important evidence for motorbike brands to improve brand equity and dimension.

\subsection{Managerial Implications}

The research results reflect positive impacts of perceived quality (.210), and brand loyalty (.245) on overall brand equity. This outcome is congruous to previous studies done by Yoo et al. (2000); Saydan (2013). Similarly, result shows that brand associations (.165) also significantly affect overall brand equity, which is similar with the result from Tong and Hawley (2009). Implications show that marketers should focus their efforts primarily on perceived quality, brand association, and brand loyalty, which have great significance in the construct of brand equity. In the motorbike market during saturation stage, the key factor for developing a brand is to improve product quality - the determining element for perceived quality from customers. Besides, brands have to generate unique, creative, distinctive, and impressive brand images to provide customers with a reason to buy the brand. In addition, brand loyalty has the most significant effect on brand equity (.245). This result reconfirms the essential role of developing brand loyalty to brand equity building in the motorbike market. Therefore, marketers should build consumer loyalty as one of its main priorities. Improving brand associations and brand loyalty can be performed partly by marketing mix elements such as promotions and advertising (Yoo et al., 2000; Buil et al., 2013).

This paper also presents the relationship between brand awareness and overall brand equity ( $\mathrm{p}$-value $=0.183$ (> $0.1)$ ) that means it is not reliable enough to approve that brand equity is influenced positively by brand awareness (BAW). This finding is consistent with a previous study by Tong and Hawley (2009). This indicates that having a familiar and well-known brand solely is not a guarantee of a successful brand in the motorbike market. However, the correlation in confirmatory factor analysis between brand awareness and brand loyalty is 0.159 . Hence, brand awareness can influence brand equity by influencing brand loyalty. This result indicates that marketers spend much of the organization's resources on perceived quality, brand association, and brand loyalty, but should not underestimate or underinvest for brand awareness.

The consequences of brand equity are also confirmed, in that brand preference and purchase intentions are significantly impacted by brand equity. These results are similar with the research of Chen and Chang (2008); Moradi and Zarei (2011); Buil et al. (2013). Result also shows that purchase intentions are also significantly affected by brand preference. This outcome is congruous to previous research done by Chen and Chang (2008); Chang and Liu (2009); Moradi and Zarei (2011); Tolba and Hassan (2009) in different markets in different countries. These results reflect the important role of brand equity and its benefits for firms. Therefore, firms should continue to establish and maintain a positive reputation in customers' minds (Chang et al., 2008). In addition, firms have to consolidate and intensify brand equity because it is a key strategy for firms to improve its position in the motorbike market. Consolidating and intensifying brand equity can be implemented by improving brand equity dimensions that is discussed above.

\subsection{Limitations and Future Research}

This study has two main limitations. Firstly, this study was conducted within three cities: Hanoi, Danang, Ho Chi Minh. Hence, future research needs to consider the extent to other cities where consumer attitudes and behaviors can be different in order to get general results for the motorbike market in Vietnam. Secondly, this research considers brand equity and its dimensions are the primary drivers of brand preference and purchase intention. Future research should identify the antecedents of brand equity and its dimensions. It would be interesting to determine which marketing activities would help increase dimensions of brand equity and overall brand equity.

\section{References}

Aaker, D. A. (1991). Managing brand equity. New York, NY: Free Press.

Agarwal, M. K., \& Rao, V. R. (1996). An empirical comparison of consumer-based measures of brand equity. Marketing Letters, 7(3), 237-247. http://dx.doi.org/10.1007/BF00435740

Bagozzi, R. P., \& Yi, Y. (1988). On the evaluation of structural equation models. Journal of Academy of Marketing Science, 16(1), 74-94. http://dx.doi.org/10.1007/BF02723327

Berry, L. L. (2000). Cultivating service brand equity. Journal of the Academy of Marketing Science, 28(1), 


\section{8-137. http://dx.doi.org/10.1177/0092070300281012}

Bowen, J. T., \& Shoemaker, S. (1998). Loyalty: A strategic commitment. Cornell Hotel and Restaurant Administration Quarterly, 39(1), 12-25. http://dx.doi.org/10.1177/001088049803900104

Buil, I., Chernatony, L., \& Martinez, E. (2013a). Examining the role of advertising and sales promotions in brand equity creation. Journal of Business Research, 66(1), 115-122. http://dx.doi.org/10.1016/j.jbusres.2011.07.030

Buil, I., Martınez, E., \& Chernatony, L. (2013b). The influence of brand equity on consumer responses. Journal of Consumer Marketing, 30(1), 62-74. http://dx.doi.org/10.1108/07363761311290849

Chang, H. H., \& Liu, Y. M. (2009). The impact of brand equity on brand preference and purchase intentions in the service industries. The Service Industries Journal, 29(12), 1687-1706. http://dx.doi.org/10.1080/02642060902793557

Chang, H. H., Hsu, C. H., \& Chung, S. H. (2008). The antecedents and consequences of brand equity in service markets. Asia Pacific Management Review, 13(3), 601-624.

Chaudhuri, A. (1995). Brand equity or double jeopardy? Journal of Product and Brand Management, 4(1), 26-32. http://dx.doi.org/10.1108/10610429510083730

Chen, C., \& Chang, Y. (2008). Airline brand equity, brand preference, and purchase intentions-The moderating effects of switching costs. Journal of Air Transport Management, 14(1), 40-42. http://dx.doi.org/10.1016/j.jairtraman.2007.11.003

Chi, H. K., Yeh, H. R., \& Yang, Y. T. (2009). The impact of brand awareness on consumer purchase intention: The mediating effect of perceived quality and brand loyalty. The Journal of International Management Studies, 4(1), 135-144.

Cobb-Walgren, C., Ruble, C. A., \& Donthu, N. (1995). Brand equity, brand preference and purchase intent. Journal of Advertising, 24(3), 25-40. http://dx.doi.org/10.1080/00913367.1995.10673481

Cronin, J. Jr., Brady, M. K., \& Hult, G. T. (2000). Assessing the effects of quality, value, and customer satisfaction on consumer behavioral intentions in service environments. Journal of Retailing, 79(2), 193-218. http://dx.doi.org/10.1016/S0022-4359(00)00028-2

Fishbein, M., \& Ajzen, I. (1975). Belief, attitude, intention and behavior: An introduction to theory and research. Addison-Wesley, Reading, MA.

Garvin, D. A. (1983). Quality on the line. Harvard Business Review, 61, 65-73.

Grover, R., \& Srinivasan, V. (1992). Evaluating the multiple effects of retail promotions on brand loyal and brand switching segments. Journal of Marketing Research, 29(1), 76-89. http://dx.doi.org/10.2307/3172494

Hoang, L. (2015). Thị truờng xe máy: Bão hòa và nguọi lạh. Retrieved February 28, 2015, from http://www.thesaigontimes.vn/125818/Thi-truong-xe-may-bao-hoa-va-nguoi-lanh.html

Hoeffler, S., \& Keller, K. K. (2003). The marketing advantages of strong brands. Brand Management, 10(6), 421-445. http://dx.doi.org/10.1057/palgrave.bm.2540139

Hu, L., \& Bentler, P. M. (1999). Cutoff criteria for fit indexes in covariance structure analysis: Conventional criteria versus new alternatives. Structural Equation Modeling, 6(1), 1-55. http://dx.doi.org/10.1080/10705519909540118

Huy, D. (2013). Cuộc chiến không khoan nhượng trên thị truờng xe máy Việt. Retrieved February 28, 2015, from http://vnexpress.net/tin-tuc/oto-xe-may/cuoc-chien-khong-khoan-nhuong-tren-thi-truong-xe-may-viet-2857 736.html

Jalilvand, M. R., Samiei, N., \& Mahdavinia, S. H. (2011). The effect of brand equity components on purchase intention: An application of Aaker's model in the automobile industry. International Business and Management, 2(2), 149-158.

Keller, K. L. (1993). Conceptualizing, measuring, and managing customer-based brand equity. Journal of Marketing, 57(1), 1-22. http://dx.doi.org/10.2307/1252054

Lassar, W., Mittal, B., \& Sharma, A. (1995). Measuring customer-based brand equity. Journal of Consumer Marketing, 12(4), 11-19. http://dx.doi.org/10.1108/07363769510095270

Moradi, H., \& Zarei, A. (2011). The impact of brand equity on purchase intention and brand preference - the 
moderating effects of country of origin image. Australian Journal of Basic and Applied Science, 5(3), 539-545.

Myers, C. A. (2003). Managing brand equity: A look at the impact of attributes. Journal of Product \& Brand Management, 12(1), 39-51. http://dx.doi.org/10.1108/10610420310463126

Nunnally, J. C., \& Bernstein, I. H. (1994). Psychometric theory (3rd ed.). New York: McGraw-Hill.

Oliver, R. L. (1997). Satisfaction: A behavioral perspective on the consumer. New York: McGraw-Hill.

Rio, A., Vazquez, R., \& Iglesias, V. (2001). The role of the brand name in obtaining differential advantages. Journal of Product \& Brand Management, 10(7), 452-465.

Saydan, R. (2013). Relationship between country of origin image and brand equity: An empirical evidence in England market. International Journal of Business and Social Science, 4(3), 78-88.

Simon, C. J., \& Sullivan, M. W. (1993). The measurement and determinants of brand equity: A financial approach. Marketing Science, 12(1), 28-52. http://dx.doi.org/10.1287/mksc.12.1.28

Tolba, A. H., \& Hassan, S. S. (2009). Linking customer based brand equity with brand market performance: A managerial approach. Journal of Product \& Brand Management, 18(5), 356-366.

Tong, X., \& Hawley, J. M. (2009). Measuring customer based brand equity: Empirical evidence from the sportswear market in China. Journal of Product \& Brand Management, 18(4), $262-271$. http://dx.doi.org/10.1108/10610420910972783

Yoo, B., Donthu, N., \& Lee, S. (2000). An examination of selected advertising and marketing mix elements and brand equity. Journal of Academic Marketing Science, 28(2), 195-211. http://dx.doi.org/10.1177/0092070300282002.

Zeithaml, V. A. (1988). Consumer perceptions of price, quality, and value: A means-end model and synthesis of evidence. Journal of Marketing, 52(3), 2-22. http://dx.doi.org/10.2307/1251446

\section{Copyrights}

Copyright for this article is retained by the author(s), with first publication rights granted to the journal.

This is an open-access article distributed under the terms and conditions of the Creative Commons Attribution license (http://creativecommons.org/licenses/by/3.0/). 